\title{
Calcic cores of plagioclase phenocrysts in andesite from Karymsky volcano: Evidence for rapid introduction by basaltic replenishment
}

\author{
Pavel E. Izbekov ] Alaska Volcano Observatory, Geophysical Institute, University of Alaska, Fairbanks, Alaska 99775- \\ John C. Eichelberger 5 7320, USA \\ Lina C. Patino ] Department of Geological Sciences, Michigan State University, East Lansing, Michigan 48824-1115, \\ Thomas A. Vogel J USA \\ Boris V. Ivanov Institute of Volcanic Geology and Geochemistry, Petropavlovsk-Kamchatsky 683006, Russia
}

\section{ABSTRACT}

Calcic cores in plagioclase of Karymsky andesite of the 19962000 eruptive cycle texturally and compositionally (both trace and major elements) mimic the plagioclase phenocrysts of basalt erupted $6 \mathrm{~km}$ away at the onset of the cycle. These observations support the view that simultaneous eruption of andesite and basalt at Karymsky in the beginning of the cycle represents an example of replenishment and eruption triggering of an andesitic reservoir. Homogeneity of andesitic output occurred within two months. This suggests to us that blending of injected basalt into reservoir magma was thorough and rapid.

Keywords: plagioclase, andesite, mixing, Kamchatka Peninsula.

\section{INTRODUCTION}

Mixing of compositionally distinct magmas is well documented by the presence of enclaves and zoning of phenocrysts in igneous rocks (Eichelberger, 1978; Davidson et al., 2001; Singer et al., 1995). Different approaches, including physical and numerical modeling, have been offered to test the possibility of mixing and to describe its mechanism (e.g., Sparks and Marshall, 1986; Bergantz and Breidenthal, 2001). The question, which is crucial for validating such models, is how fast can the compositionally distinct magmas mix? Unfortunately, there are few volcanic eruptions where a detailed historical record can be used to determine the dynamics of mixing (e.g., Nakamura, 1995).

In this paper we present results of a textural and compositional study of plagioclases from andesite and basalt that erupted simultaneously at the Karymsky volcanic center beginning in January 1996. Textural observations coupled with electron-probe microanalysis (EPMA) and laser-ablation inductively coupled plasma-mass spectrometry (LA-ICP-MS) indicate that calcic cores in plagioclases of Karymsky andesites are identical to plagioclase phenocrysts of basalts. We argue from the surface expression of the system, eruption record, and petrology that the sequence represents interception of an andesitic magma pod by a rising basalt dike that produced a uniform mixture within two months.

\section{GEOLOGIC FRAMEWORK}

The Karymsky volcano and Academy Nauk caldera belong to a chain of volcanoes, calderas, and maars, the location of which is controlled by a local north-trending fault (Fig. 1). Magmas erupted during Holocene time along the fault varied in composition from basalts to rhyolites, andesites and dacites being the most voluminous. Basalt eruptions in the Karymsky-Academy Nauk area have been rare and subordinate in volume.

Karymsky is an $\sim 5300$-yr-old andesitic stratovolcano located in the center of an $\sim 7900$-yr-old caldera (Braitseva and Melekestsev, 1991). During the past $500 \mathrm{yr}$, the volcano has been in a state of frequent but intermittent activity. In the twentieth century Karymsky had 7 periods of continuous Strombolian eruptive activity, each lasting from 4 to $15 \mathrm{yr}$ (Ivanov, 1970).

The Academy Nauk caldera is centered 9 km south of Karymsky on the same fault system. Since its caldera-forming event (ca. $40 \mathrm{ka}$ ), the volcanic activity within the caldera was confined to phreatomagmatic eruptions of basalt that have occurred at least twice since $5 \mathrm{ka}$ (Belousov and Belousova, 2001). These eruptions formed distinctive maars in the northern and southern parts of the caldera.

\section{SIMULTANEOUS ERUPTION OF ANDESITE AND BASALT IN 1996}

The most recent episode of volcanic activity at Karymsky started on January 2, 1996, after $13 \mathrm{yr}$ of dormancy. It began with simultaneous eruption of andesite from the central vent of Karymsky volcano and basalt from a new vent, which formed in the northern part of Academy Nauk caldera (Fig. 1). The phreatomagmatic eruption of the Academy Nauk center was over in $<18 \mathrm{~h}$, whereas Vulcanian and then low-level Strombolian eruption of Karymsky continued for 4 yr. Omitting the details of the eruption, which can be found in Muravyev et al. (1998), we emphasize its main characteristics relevant to this study.

First, the magmas erupted from neighboring vents had strongly contrasting bulk compositions. The Academy Nauk vent produced basalt $\left(52.2 \mathrm{wt} \% \mathrm{SiO}_{2}\right)$, and the Karymsky summit vent erupted andesite $\left(62.4 \mathrm{wt} \% \mathrm{SiO}_{2}\right)$. The latter was almost identical to andesites produced during previous periods of activity. The magmas were compositionally

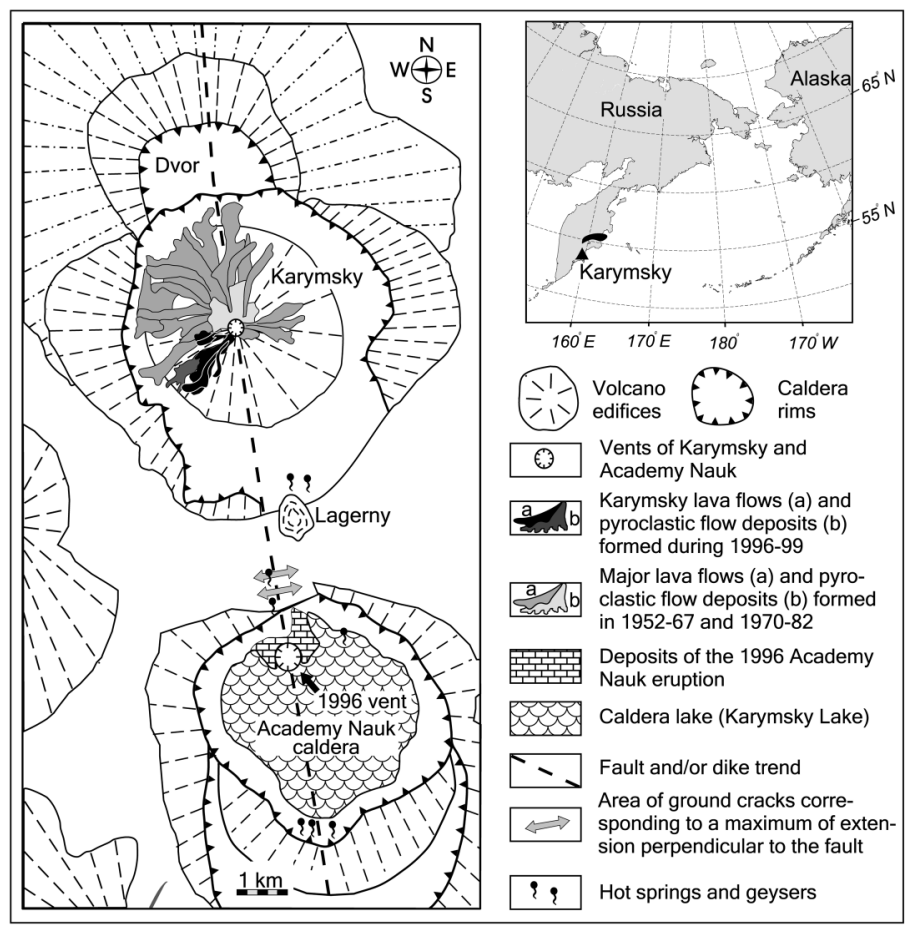

Figure 1. Generalized map of Karymsky and Academy Nauk. The 1996-2000 eruptive cycle started with simultaneous eruption of andesite from Karymsky summit vent and basalt from new vent formed in northern part of Academy Nauk caldera. 
distinct and lacked evidence of mechanical mixing (mingling), i.e., no mafic enclaves were found in andesites, nor were bands or blobs of andesite found in basalt, and no intermediate compositions were erupted.

Second, significant ground deformation occurred between eruptive vents. Cracks as long as $700 \mathrm{~m}$ were formed parallel to the northtrending fault (Leonov, 1998). The area of major ground cracks coincides with a maximum in west-east extension, reaching an amplitude of $2.33 \mathrm{~m}$ (Maguskin et al., 1998). Extension between eruptive vents occurred gradually, which is consistent with propagation of basaltic dike along the active fault. Because Karymsky is well within the domain of measurable extension, such a dike could have intercepted a crustal magma system beneath Karymsky.

Third, within two months of the onset of eruption, the composition of melt of Karymsky andesite, as recorded by glass in tephra, shifted toward a more mafic composition and then gradually returned to its original state and remained constant for the rest of the eruption. The large amplitude of the chemical shift in melt composition cannot be explained by variations in magma flux that yielded variable rates of syneruptive crystallization; the large chemical shift requires addition of a mafic melt to the original melt of the andesite (Eichelberger and Izbekov, 2000). Because the eruptive batches of Karymsky andesite magma are plagioclase rich and chemically monotonous, they likely represent small episodic withdrawals from the same larger, well-stirred, crustal reservoir. The eruption of basalt coincident with the start of the most recent cycle is suggestive of eruptive triggering, and the early shift in melt composition is at least consistent with some contact between stored andesite and injected basalt.

The foregoing characteristics of eruption indicate that in 1996, at the beginning of a $4 \mathrm{yr}$ cycle of activity, a crustal reservoir of Karymsky was replenished by basalt. Whether the replenishment led to a complete blending of basalt into andesite in a period of time as short as two months could not be determined unless xenocrysts of basaltic origin could be found in andesite. Plagioclase was chosen for tracing basaltic xenocrysts in andesite because (1) plagioclase is the dominant phase of both basalt and andesite, (2) plagioclases of basaltic and andesitic provenance should be significantly different in composition and thus easily distinguishable, and (3) diffusion rates in plagioclase are slow, so that compositions from the time of growth are preserved despite changes in physical conditions of the magma or composition of the coexisting melt (e.g., Grove et al., 1984).

\section{ANALYTICAL TECHNIQUES}

The major element composition of plagioclase phenocrysts was analyzed by using the Cameca SX 50 electron microprobe at the University of Alaska, Fairbanks. Analytical conditions were $15 \mathrm{kV}$ accelerating voltage, $10 \mathrm{nA}$ beam current, and 1-3 $\mu \mathrm{m}$ focused electron beam. Backscattered-electron (BSE) images of plagioclase phenocrysts were acquired in raster mode at $15 \mathrm{kV}$ and $80-150 \mathrm{nA}$ beam current.

Because $\mathrm{Sr}$ and $\mathrm{Ba}$ are the most abundant trace elements in plagioclases and because their partitioning behavior is well defined by analytical and experimental work (e.g., Blundy and Wood, 1991; Bindeman and Bailey, 1999), they were chosen for fingerprinting plagioclases of different provenance. $\mathrm{Sr}$ and $\mathrm{Ba}$ contents in multiple spots along microprobe traverses of representative plagioclase phenocrysts were analyzed by using a Micromass Plasma ICP-MS coupled with a Cetac LSX 200 laser-ablation system at Michigan State University. The $266 \mathrm{~nm} \mathrm{Nd}: Y A G$ laser was focused to a $25 \mu \mathrm{m}$ sampling spot size and propagated into the sample with a rate of $3 \mu \mathrm{m} / \mathrm{s}$. The concentrations of $\mathrm{Sr}$ and $\mathrm{Ba}$ were calculated by using peak intensities of ${ }^{88} \mathrm{Sr},{ }^{138} \mathrm{Ba}$, and ${ }^{44} \mathrm{Ca}$ calibrated against a NIST 612 glass standard and EPMA determinations of $\mathrm{Ca}$ in analyzed spots as outlined in Norman et al. (1996).
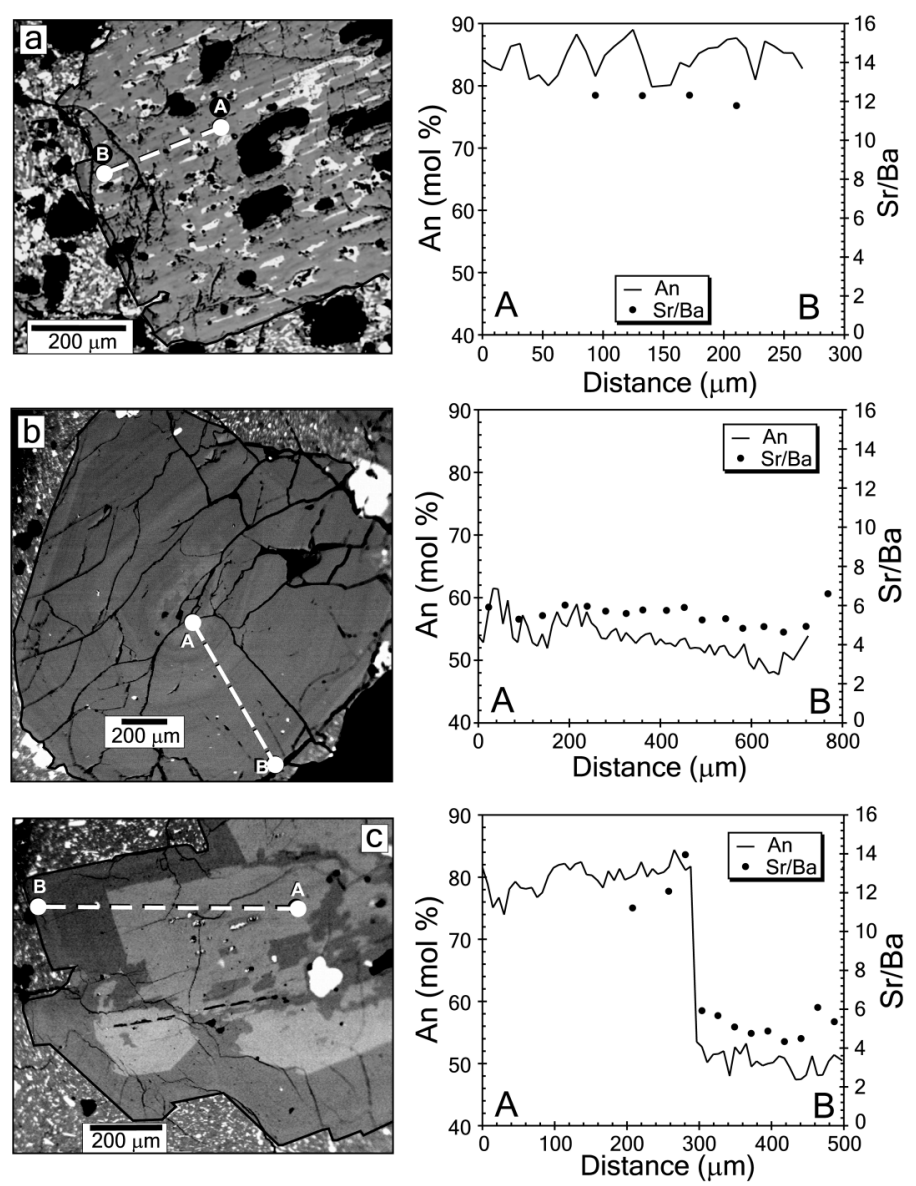

Figure 2. Backscattered-electron images and compositional diagrams of representative plagioclases. a: Coarse-sieved plagioclase phenocryst from Academy Nauk basalt erupted on January 2, 1996. b: Oscillatory zoned plagioclase from Karymsky andesite erupted on February 17, 1996. c: Rimmed (calcic-cored) plagioclase from Karymsky andesite erupted in July 1998.

\section{TYPES OF PLAGIOCLASE}

Plagioclase phenocrysts make up 30-35 vol\% of Academy Nauk basalt and show little variation in composition or texture. The majority of plagioclase phenocrysts in Academy Nauk basalt are euhedral and have a coarse-sieved interior (Fig. 2a). The coarse-sieved texture is due to the presence of abundant melt inclusions, which vary from circular to elongate and irregular. The high concentration of inclusions suggests that they form a system of interconnected channels permeating the crystals' interiors. This coarse-sieved texture resembles that reproduced in decompression (Nelson and Montana, 1992) and heating (Johannes et al., 1994) experiments, where the texture results from dissolution rather than skeletal growth. Both melt inclusions and matrix glass are commonly vesicle rich and microlite rich, attributes that could be due to coupled syneruptive vesiculation and crystallization (Blundy and Cashman, 2001). The similarity of the melt inclusions in the plagioclase to the matrix glass and evidence of their syneruptive vesiculation indicate that the system of interconnected melt channels within plagioclase phenocrysts was open with respect to the surrounding medium during magma ascent.

Compositions of plagioclase cores, rims, subphenocrysts, and microlites of Academy Nauk basalt are nearly constant at 80-90 mol\% anorthite (An) (Figs. 2 and 3A). EPMA profiles across phenocrysts show either oscillatory or, rarely, normal zoning. $\mathrm{Sr} / \mathrm{Ba}$ ratios of basaltic plagioclases are high and form a distinctive isolated cluster in composition space (Fig. 3B).

Plagioclase phenocrysts form 20-25 vol\% of Karymsky andesite. 


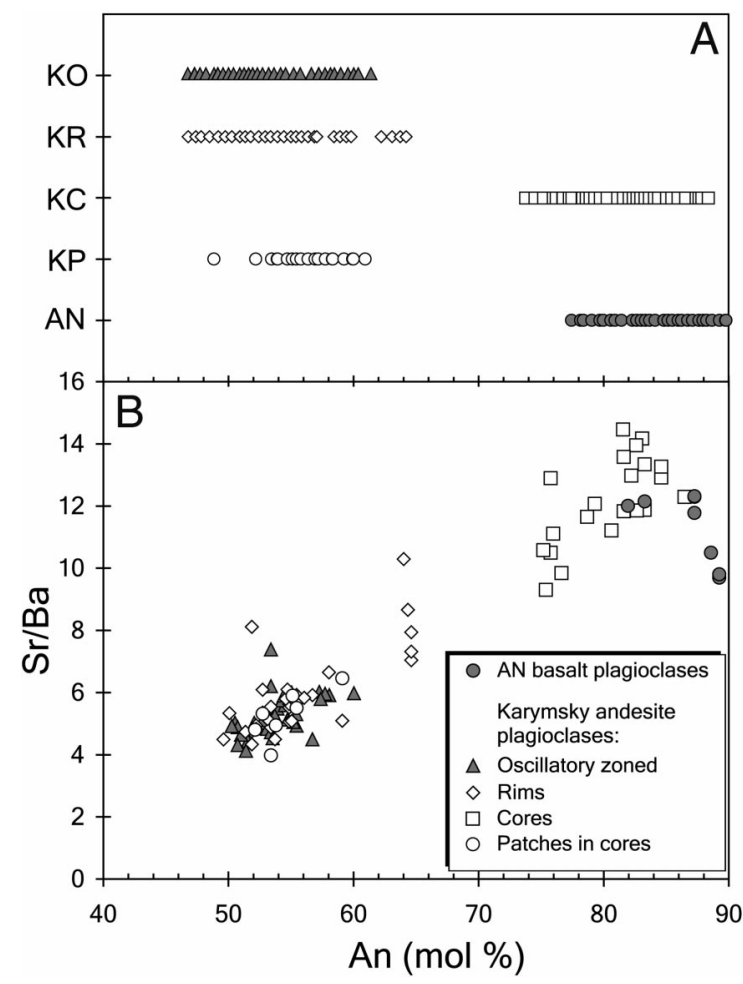

Figure 3. Compositions of plagioclases in Karymsky andesite (KO-oscillatory zoned plagioclase, KR-rims of rimmed plagioclase, $\mathrm{KC}$-cores of rimmed plagioclase, $\mathrm{KP}$-patches in calcic cores) and in Academy Nauk basalt (AN).

Unlike the plagioclase in basalt, they show significant variations in composition and texture. The majority of the plagioclases occur in two distinctive populations: (1) oscillatory zoned sodic plagioclases $\left(\mathrm{An}_{48-62}\right)$ and (2) rimmed plagioclases, characterized by the presence of calcic cores $\left(\mathrm{An}_{76-90}\right)$ and sodic rims $\left(\mathrm{An}_{48-62}\right)$. Oscillatory zoned plagioclases make up 70\%-80\% of all phenocrysts and the majority of subphenocrysts (Fig. 2b). Their EPMA profiles usually show fine oscillation superimposed on a weak normal zoning; small jumps in An content occur at major dissolution surfaces. $\mathrm{Sr} / \mathrm{Ba}$ ratios of oscillatory zoned plagioclases of the andesite are significantly lower than in plagioclases of the basalt, forming an isolated cluster without any overlap on a composition diagram (Fig. 3B).

Rimmed plagioclases occurred in Karymsky andesite throughout the 1996-2000 cycle of activity and were present in previously erupted andesite batches. They consist of euhedral calcic cores, often with coarse-sieved interiors, and oscillatory zoned rims. The texture of calcic cores mimics that of plagioclase in basalt, but unlike the latter, voids are filled with sodic plagioclase and melt, rather than with melt only, forming a texture frequently referred to as patchy zoning (Vance, 1965).

Both EPMA and LA-ICP-MS analyses show that the andesitic plagioclases' calcic cores are compositionally similar to plagioclases in basalt (Fig. 3, A and B), whereas compositions of rims outside and patches inside calcic cores are close to the composition of oscillatory zoned plagioclases. A BSE image and an EPMA profile of a rimmed plagioclase in andesite (from a volcanic bomb erupted $2.7 \mathrm{yr}$ after the beginning of eruption) show an abrupt boundary between core and rim, where composition changes from $\mathrm{An}_{80}$ to $\mathrm{An}_{52}$ within $30 \mu \mathrm{m}$ (Fig. 2c). Its rim lacks major dissolution surfaces and associated jumps in An content, which are characteristic for large oscillatory zoned plagioclases.

\section{ORIGIN OF CALCIC PLAGIOCLASES IN KARYMSKY ANDESITE}

The presence of calcic cores in plagioclases of Karymsky andesites and their striking similarity to plagioclases in simultaneously erupted basalt raise three questions. First, could the calcic cores crystallize in andesite, or were they introduced from a more mafic source as xenocrysts? Second, if the latter is correct, what is the possibility that their source magma was compositionally similar to Academy Nauk basalt? Third, have the calcic cores been introduced into the andesite by the same basalt as erupted in the Academy Nauk caldera at the beginning of the 1996-2000 cycle of eruptive activity?

Experimental data on equilibrium crystallization in magma systems led to the development of numerical models that can be used for simulating phase equilibria in crystallizing andesites and basalts. One of them, COMAGMAT (Ariskin, 1999), was used here for evaluating the possibility that calcic cores could represent an early stage of crystallization of Karymsky andesites at higher temperature, pressure, and, in general, lower crystallinity. The results of calculations show that in a magma with the bulk chemical composition of Karymsky andesite, the An content of plagioclase would not exceed $48-52 \mathrm{~mol} \%$ at pressures of $0.1-200 \mathrm{MPa}$, temperatures of $800-1300{ }^{\circ} \mathrm{C}$, and water contents of 0-4 wt $\%$. The predicted composition of plagioclase is in close agreement with the composition of oscillatory zoned plagioclases and rims of calcic-cored plagioclases $\left(\mathrm{An}_{48-62}\right)$. Plagioclase as calcic as $\mathrm{An}_{76-90}$ could not crystallize in equilibrium in andesite magma at any plausible pressure, temperature, and water content, and thus must have been introduced to the Karymsky andesite magma from a more mafic source.

Chemically homogeneous $\mathrm{An}_{80-90}$ plagioclase is the dominant mineral phase of Academy Nauk basalt, thus implying that this plagioclase crystallized in magma of Academy Nauk basalt chemistry, an inference supported by the COMAGMAT model. Hence, the compositional similarity of the calcic cores in Karymsky andesite to plagioclase from Academy Nauk basalt suggests that they crystallized at comparable pressure-temperature $(P-T)$ conditions in a basaltic magma of similar chemistry. In addition, the textural similarity of calcic plagioclase cores in andesite and plagioclase in basalt, i.e., their coarsesieved interiors, suggests that the cores were subjected to the same process of dissolution prior to incorporation into andesite magma, perhaps linked to the decompression of ascending basalt (Coombs et al., 2000; Nelson and Montana, 1992). We conclude that the calcic plagioclase cores in Karymsky andesite followed the same $P-T$ path as plagioclase phenocrysts in Academy Nauk basalt, except that they became incorporated in Karymsky andesite prior to eruption.

Similarity to plagioclases in Academy Nauk basalt, however, does not necessarily imply that xenocrysts of calcic plagioclase were introduced to the andesite in 1996. Although characteristics of the 1996 eruption make it reasonable to suggest that this interpretation might be the case, calcic cores occur in plagioclases of earlier eruptions of $\mathrm{Ka}$ rymsky. If these eruptions were triggered by basaltic recharges that did not vent directly to the surface and the invading basalts had the same chemical and mineral compositions as Academy Nauk basalt, as seems plausible, then additional evidence is required for identification of those xenocrysts introduced by 1996 replenishment.

Chemical variations, texture, and width of rims of calcic-cored plagioclases might be used to distinguish calcic cores introduced by the most recent basaltic recharge from those previously introduced. Large oscillatory zoned plagioclase crystals, which were present in the andesite from the beginning of the 1996-2000 eruption (Fig. 2b), exhibit multiple 6\%-10\% jumps in An content associated with major dissolution surfaces. If, as seems likely, the outermost one formed in 1996, the inner jumps are most likely linked to basaltic recharges that occurred prior to 1996. If already present in Karymsky andesite, the 
rim of a calcic-cored plagioclase would have been subjected to similar disturbances, subsequent to the basaltic replenishment that introduced its calcic core to the andesite magma. The absence of major dissolution surfaces and associated increases in An content in the rim (Fig. 2c) suggest to us that the calcic core of the phenocryst was introduced by the most recent basaltic replenishment.

Width of the rim may also be used as a criterion for distinguishing between the most recently introduced xenocrysts and the older ones by assuming plausible growth rates. Although we did not attempt to quantify variations in rim width with time of eruption, rims of plagioclases in andesites erupted 2-4 months after the beginning of eruption appear to be smaller compared to ones erupted 2-3 yr after that. Of course, apparent width is also a function of a crystal's orientation in thin section, i.e., the observed width is equal to or greater than the actual width, and therefore an inferred growth rate will be equal to, or greater than, the actual growth rate. If the calcic core of plagioclase shown in Figure 2c was introduced to the andesite magma in January 1996 , then the $200-\mu \mathrm{m}$-wide sodic rim of this phenocryst was formed during the following $2.7 \mathrm{yr}$. This scenario requires the maximum plagioclase growth rate in the Karymsky reservoir to be on the order of $2.5 \times 10^{-9} \mathrm{~mm} / \mathrm{s}$, which is consistent with growth rates determined experimentally (e.g., Hammer and Rutherford, 2002). Thus, in the 1996-2000 Karymsky eruption, the calcic cores in plagioclase crystals with rims characterized by absence of major dissolution surfaces and associated jumps in An content may well have been introduced to the andesite system by the same basalt that erupted in the Academy Nauk caldera in January 1996.

\section{IMPORTANCE OF THE KARYMSKY CASE}

Micrometer-scale major and trace element data provide a fingerprint for phenocrysts of different origins. Academy Nauk basalt carrying plagioclase with distinctively high An contents and $\mathrm{Sr} / \mathrm{Ba}$ ratios was apparently injected into the andesite magma system beneath Karymsky in the beginning of the 1996-2000 eruptive cycle. Homogeneity of andesite erupted by late February 1996 suggests to us that thorough mixing of injected basalt and andesite occurred in a period of time as short as two months. Perhaps the rapid and effective blending was facilitated by an only modest contrast in viscosities and temperatures between the magmas and by a vigorous fluid dynamic regime in the Karymsky reservoir. In this respect, Karymsky is a well-mixed end-member case that reflects the short recurrence interval of recharges to the system. In contrast, Trident volcano in Alaska may represent an intermediate case, where both clotting and direct mixing occurs (Coombs et al., 2000), and Soufriere Hills in Montserrat may represent a poorly mixed end-member case, where clotting alone is dominant (Murphy et al., 2000).

\section{ACKNOWLEDGMENTS}

This work was supported by the Volcano Hazards Program of the U.S. Geological Survey through the Alaska Volcano Observatory. Additional funding for field trips to Karymsky was provided by Russian Foundation for Basic Research grant 99-05-65495. Comments by George Bergantz, Jon Davidson, and Ben A. van der Pluijm significantly improved the manuscript.

\section{REFERENCES CITED}

Ariskin, A.A., 1999, Phase equilibria modeling in igneous petrology: Use of COMAGMAT model for simulating fractionation of ferro-basaltic magmas and the genesis of high-alumina basalt: Journal of Volcanology and Geothermal Research, v. 90, p. 115-162.

Belousov, A., and Belousova, M., 2001, Eruptive process, effects and deposits of the 1996 and ancient basaltic phreatomagmatic eruptions in Karymskoye Lake, Kamchatka, Russia, in White, J.D.L., and Riggs, N.R., eds., Volcaniclastic sedimentation in lacustrine settings: International Association of Sedimentologists Special Publication 30, p. 35-60.

Bergantz, G.W., and Breidenthal, R.E., 2001, Non-stationary entrainment and tunneling eruptions; a dynamic link between eruption processes and magma mixing: Geophysical Research Letters, v. 28, p. 3075-3078.
Bindeman, I.N., and Bailey, J.C., 1999, Trace elements in anorthite megacrysts from the Kurile island arc: A window to across-arc geochemical variations in magma compositions: Earth and Planetary Science Letters, v. 169, p. 209-226.

Blundy, J., and Cashman, K., 2001, Ascent-driven crystallization of dacite magmas at Mount St. Helens, 1980-1986: Contributions to Mineralogy and Petrology, v. 140 , p. 631-650.

Blundy, J., and Wood, B., 1991, Crystal-chemical controls on the partitioning of $\mathrm{Sr}$ and $\mathrm{Ba}$ between plagioclase feldspar, silicate melts, and hydrothermal solutions: Geochimica et Cosmochimica Acta, v. 55, p. 193-209.

Braitseva, O.A., and Melekestsev, I.V., 1991, Eruptive history of Karymsky volcano, Kamchatka, USSR, based on tephra stratigraphy and ${ }^{14} \mathrm{C}$ dating: Bulletin of Volcanology, v. 53, p. 195-206.

Coombs, M.L., Eichelberger, J.C., and Rutherford, M.J., 2000, Magma storage and mixing conditions for the 1953-1974 eruptions of Southwest Trident volcano, Katmai National Park, Alaska: Contributions to Mineralogy and Petrology, v. 140, p. 99-118.

Davidson, J., Tepley, F., III, Palacz, Z., and Meffan-Main, S., 2001, Magma recharge, contamination and residence times revealed by in situ laser ablation isotopic analysis of feldspar in volcanic rocks: Earth and Planetary Science Letters, v. 184, p. 427-442.

Eichelberger, J.C., 1978, Andesitic volcanism and crustal evolution: Nature, v. 275 , p. $21-27$.

Eichelberger, J.C., and Izbekov, P.E., 2000, Eruption of andesite triggered by dyke injection: Contrasting cases at Karymsky volcano, Kamchatka and Mt. Katmai, Alaska: Royal Society of London Philosophical Transactions, ser. B, v. 358, p. 1465-1485.

Grove, T.L., Baker, M.B., and Kinzler, R.J., 1984, Coupled CaAl-NaSi diffusion in plagioclase feldspar: Experiments and applications to cooling rate speedometry: Geochimica et Cosmochimica Acta, v. 48, p. 2113-2121.

Hammer, J.E., and Rutherford, M.J., 2002, An experimental study of the kinetics of decompression-induced crystallization in silicic melt: Journal of Geophysical Research, v. 107, no. B1, p. ECV 8-1-8-24.

Ivanov, B.V., 1970, Eruption of Karymsky volcano during 1962-65 and the Karymsky volcanic group: Moscow, Nauka, 135 p.

Johannes, W., Koepke, J., and Behrens, H., 1994, Partial melting reactions of plagioclases and plagioclase-bearing systems, in Parsons, I.E., ed., Feldspars and their reactions: Edinburgh, United Kingdom, D. Reidel Publishing Company, p. 161-194.

Leonov, V.L., 1998, Ground surface breaks produced by an earthquake and volcanic eruptions in the Karymsky volcanic center on January 1-2, 1996: Volcanology and Seismology, v. 19, p. 655-674.

Maguskin, M.A., Fedotov, S.A., Levin, V.E., and Bakhtiarov, B.F., 1998 Ground surface deformation caused by seismic and volcanic activity in the Karymsky volcanic center during January 1996: Volcanology and Seismology, v. 19, p. 637-654.

Muravyev, Y.D., Fedotov, S.A., Budnikov, V.A., Ozerov, A.Y., Magus'kin M.A., Dvigalo, V.N., Andreyev, V.I., Ivanov, V.V., Kartasheva, L.A., and Markov, I.A., 1998, Volcanic activity in the Karymsky center in 1996: Summit eruption at Karymsky and phreatomagmatic eruption in the Akademii Nauk Caldera: Volcanology and Seismology, v. 19, p. 567-604.

Murphy, M.D., Sparks, R.S.J., Barclay, J., Carroll, M.R., and Brewer, T.S., 2000, Remobilization of andesite magma by intrusion of mafic magma at the Soufriere Hills Volcano, Montserrat, West Indies: Journal of Petrology, v. 41, p. $21-42$.

Nakamura, M., 1995, Continuous mixing of crystal mush and replenished magma in the ongoing Unzen eruption: Geology, v. 23, p. 807-810.

Nelson, S.T., and Montana, A., 1992, Sieve-textured plagioclase in volcanic rocks produced by rapid decompression: American Mineralogist, v. 77, p. $1242-1249$

Norman, M.D., Pearson, N.J., Sharma, A., and Griffin, W.L., 1996, Quantitative analysis of trace elements in geological materials by laser ablation ICPMS Instrumental operating conditions and calibration values of NIST glasses: Geostandards Newsletter, v. 20, p. 247-261.

Singer, B.S., Dungan, M.A., and Layne, G.D., 1995, Textures and Sr, Ba, Mg, $\mathrm{Fe}, \mathrm{K}$ and $\mathrm{Ti}$ compositional profiles in volcanic plagioclase: Clues to the dynamics of calc-alkaline magma chambers: American Mineralogist, v. 80 , p. $776-798$

Sparks, R.S.J., and Marshall, L.A., 1986, Thermal and mechanical constraints on mixing between mafic and silicic magmas: Journal of Volcanology and Geothermal Research, v. 29, p. 99-124.

Vance, J.A., 1965, Zoning in igneous plagioclase: Patchy zoning: Journal of Geology, v. 73, p. 636-651.

Manuscript received January 27, 2002

Revised manuscript received May 8, 2002

Manuscript accepted May 10, 2002

Printed in USA 